\title{
The Impact of Futures Trading Over Spot Market Intraday Volatility: Evidence From an Emerging Market, Borsa Istanbul
}

\author{
Mustafa OKUR $^{1} \quad$ Gulcan CAGIL $^{2}$ Ercan KIRAN ${ }^{3}$ \\ 1.Department of Capital Markets, Marmara University, Turkey \\ 2.Department of Actuarial Sciences, Marmara University, Turkey \\ 3.Director, Debt Securities Market, Borsa Istanbul, Turkey
}

\begin{abstract}
The objective of this article is to examine the impact of stock index futures on stock markets. Of particular interest is the evidence for change in overall volatility and liquidity after the introduction of stock index futures. The impact of derivatives trading on price volatility in the underlying spot market return is examined using the exponential GARCH (EGARCH) model which was proposed by Nelson (1991). Our empirical findings support the view that introducing futures trading decreases volatility in the spot market and the speed with which market information is reflected in spot market prices. However, volatility persistence increased in the post-futures period. In the light of these findings it can be said that the speed and nature of information differ between pre-futures period and post-futures period.
\end{abstract}

JEL Classification: G13, G14, G32

Keywords: Futures Markets, Spot Markets, Volatility, GARCH Models, Emerging Markets

DOI: $10.7176 / \mathrm{RJFA} / 10-2-07$

\section{Introduction}

Stock index futures are perceived as one of the most successful financial innovations of the 1980s. Trading based on this financial instrument was first introduced in February 1982 by the Kansas City Board of Trade in the USA and other developed markets soon followed. In contrast, much of the futures trading in emerging markets are a recent phenomenon (Ryoo and Smith, 2004). Although Borsa İstanbul is one of the fastest growing emerging markets, it was not until 4 Feb. 2005 that a futures contract based on Borsa Istanbul National-30 (BIST 30 Futures) was introduced on the Turkish Derivatives Exchange. After their introduction, trading in these stock index futures increased remarkably. It also should be highlighted that in recent years, Borsa Istanbul is taking important steps in order to become a regional hub in accordance with the "İstanbul İnternational Financial Center" project of Turkish Government.

The interaction between the spot and future markets has been one of the most important topics in finance literature, especially after sharp stock market crashes. The impact of derivative trading on spot price volatility has been widely investigated for major markets. GARCH type models are the most successful and popular models used in modeling the volatility in financial markets. In literature, Autoregressive Conditional Heteroscedasticity model was first proposed by Engle (1982). Then the model was extended by Bollerslev (1986) to its generalized version $(\mathrm{GARCH})$.

Over the past 20 years, a considerable amount of research used GARCH methodology in order to investigate the relationship between futures market and the associated spot market. Finance literature related to spot volatility and future trading can be classified in three groups.

(a) Various researchers have inferred that future trading increases spot volatility. Harris (1989) researched the change in the volatility of S\&P 500 index before and after the introduction of futures. He found out that volatility of the S\&P 500 index increased after the start of trade in index futures and index options in 1983. Holmes's paper (1995), examines the impact of futures trading on price volatility in the underlying spot market for a contract, the FTSE Eurotrack. In the paper, daily closing price indexes for the period June 1990 to April 1994 are used. Futures trading increases the rate at which information is impounded into prices and reduces persistence. Antoniou and Holmes's study (1995) examines the impact of trading in the FTSE-100 Stock Index Futures on the volatility of the underlying spot market. Authors used daily closing price indices between November 1980 to October 1991, and the results suggest that futures trading improves the quality and speed of information flowing to spot markets. The evidence suggests there has been an increase in spot price volatility on a daily basis. Gulen and Mayhew (2000) examined stock market volatility before and after the introduction of equity-index futures trading in twenty-five countries, using various statistical models. They found that futures trading is related to an increase in conditional volatility only in the United States and Japan, but in nearly every other country, they found either no significant effect or a volatility-dampening effect. Brooks, Rew and Ritson (2001) examined the lead-lag relationship between the FTSE 100 index and index futures price employing several time series models. Using 10-min observations from June 1996-1997, it is found that lagged changes in the futures price can be used to predict the changes in spot prices. Chiang and Wang (2002), looked into the effect Taiwan Index futures trading on the spot price volatility on the Taiwan Stock Exchange for the period 
between $5^{\text {th }}$ January 1995 to $10^{\text {th }}$ May 2000 by using daily data. They evidenced trading Taiwan Index Futures (TAIEX) has a major effect on spot price volatility, whereas trading Morgan-Stanley Capital International Taiwan Index (MSCI), which are traded on the Singapore Exchange, does not. Ryoo and Smith (2004), investigated the impact of futures trading on the spot market in Korea for the period between September 1993 to December 1998 by using daily and five minute data with GARCH method. They empirically showed that futures trading increases the speed at which information is impounded into spot market prices, reduces the persistence of volatility and increases spot market volatility. Pok and Poshakwale (2004) examined the impact of futures trading on spot market volatility in the Malaysian stock market with GARCH method by using daily data and a proxy variable. They provided evidence on that futures trading increases spot market volatility and the flow of information to the spot market. Sequeira et al. (2004) examined volatility models of currency futures contracts for three developed markets and two emerging markets. Their empirical results support the view that the conditional volatility of futures returns for emerging markets is significant in explaining the conditional volatility of returns in the underlying spot market and the opposite for the developed markets. Floros and Vougas (2006) found that the introduction of stock index futures has increased the volatility of the FTSE/ASE Mid 40 index. Alexakis (2007) examined the impact of futures trading on spot market price volatility in the FTSE/ASE-20 stock index market of the ATHEX, for the period 23 September 1997 to 04 June 2004 by using the GJRGARCH model, especially to take into account the link between information and volatility. The findings indicate that the index of futures trading is fully consistent with efficient market operation as it exerts a stabilising effect in the spot market, reducing volatility asymmetries and improves the quality and speed of the flow of information. Pati and Rajib (2011) examined the relationship between the National Stock Exchange (NSE) S\&P CNX Nifty futures and its underlying spot index in terms of both return and volatility by using intraday data. In order to examine the volatility spillovers between the markets they used GARCH $(1,1)$ model. Their empirical findings suggest that Nifty futures prices lead spot prices and futures market largely contributes to price discovery.

(b) The opponents believing above corroborate that future trading decreases spot volatility. Bessembinder and Seguin (1992) examined relationship between spot-and futures-trading and daily volatility in United States Equity Markets. Their findings are consistent with theories predicting that active futures markets enhance the liquidity and depth of the equity markets. Antoniou, Holmes and Priestly (1998), examined the impact of futures trading on daily stock market volatility by using GARCH estimation with daily closing prices. They used the data of six developed stock markets (Germany, Japan, Spain, Switzerland, UK and US) for the analysis. They found that, for Germany and Switzerland, introduction of futures trading had a significant negative effect on the volatility of the spot market. Bologna and Cavallo (2002) used GARCH estimation to analyze the relationship between stock index futures and corresponding stock market volatility on the MIB30 index in the Italian market. The results showed introducing stock index futures decreased the stock market volatility. Floros and Vougas (2006), Drimbetas et al.(2007) examined the effects of the introduction of the futures and options by using daily closing price on the volatility of the FTSE/ASE 20 index in Greek stock market. Their results suggested introducing derivatives had induced a reduction of the conditional volatility of the underlying 20 index. Pilar and Rafael (2002) studied the effect of the introduction of derivatives index of the Spanish Market on the volatility and on the trading volume of the Ibex35. The period analyzed covers from October 1990 to December 1994. Results obtained prove a decrease in the volatility and an increase in the trading volume of the Ibex-35 since the derivative markets were introduced. Srinivasan and Bhat (2008) examined the impact of futures trading on spot market volatility of the selected twenty-one commercial banking stocks in India by using EGARCH method and daily closing price returns. The analysis reveals most of the selected commercial banking stocks reveal an introduction of futures markets declined the volatility of stock market. Pradhan (2008) and Tripathy et al. (2009) investigated the impact of futures trading on daily spot market volatility in India. The empirical findings of the three studies are similar. They evidenced that the introduction of derivatives have positively affected the daily volatility in the associated spot market. Fong and Han (2015) examined the impacts of futures and options markets on the volatility of the spot market. The results suggest that the impacts on the spot market volatility depends on the quality of new information generated by derivatives trading. In addition, the findings show that the futures market provides new, material information reducing spot market volatility. Yilgor and Mebounou (2016) examined the impact of the derivatives markets on the Turkish spot market volatility and liquidity from January 2001 to December 2014 period by using EGARCH model and ARMA model. The findings indicate that derivatives markets reduce the spot market volatility. Another important findings showed that while an unexpected future trading volume increase the spot market volatility, an expected future trading volume does not have a significant impact on the spot market volatility.

(c) Finally in literature there are also researches inferring the introduction of futures has no significant effect over spot market volatility. Choi and Subrahmanyan (1994) found no evidence supporting the hypothesis that index futures can destabilize the underlying stock markets by encouraging non-rational speculation and index arbitrage-related trading. They implied that spread or volatility changes caused by the introduction of the 
MMI futures contract are quite small, if any. In addition, the introduction of the futures contract appears to have increased trading volume and the flow of information to the underlying stock markets, thus possibly increasing their efficiency. Darrat and Rahman (1995) concluded that S\&P 500 futures volume did not have an effect on spot market volatility. They suggested that futures trading activity is not a force behind the recent episodes of jump volatility. Illueca and Lafuente (2003) examined the intraday relation between spot volatility and trading volume in Spanish Stock Index Futures Market. They used GARCH methodology to estimate spot volatility and found no evidence supporting that futures trading increased spot market volatility. Spyrou (2005) investigated whether the volatility of the FTSE/ASE-20 Index and the ASE General Price Index has been affected by the introduction of futures contract on the FTSE/ASE-20 Index with the help of GARCH models. The data set used is between January 1997 and September 2003. He evidenced that future trading has no effect on the volatility of the underlying market. Xie and Huang (2014) examined the impact of index futures trading on the volatility of the spot market in China by using daily data of the China Securities Index 300 with GARCH models from 2005 to 2012 period. The results indicated that the introduction of the CSI 300 index futures does not significantly reduce the overall volatility in the spot market or influence the nature of that volatility. Furthermore, no leverage effect is found either before or after the introduction of the CSI 300 index futures.

As it is presented in the previous paragraphs, there are three different views about the effect of introduction of futures on the related spot market volatility. The supporters of first view argue that the introduction of futures has a positive impact on the spot market volatility. The rationale behind this view is the introduction of futures enhances the liquidity and deepens the market. As a result of these positive effects the volatility of the market decreases. On the contrary, opponents of the first view claim that the introduction of futures has a negative impact on the associated spot market volatility. This is because of the increased speculator's effect over the market. In futures market investors can take highly leveraged positions. In the futures market, leverage refers to having control over large cash amounts of commodities with comparatively small levels of capital. The last view is, the introduction of the futures has no significant impact over related spot market volatility. They argue that the changes in the spot market volatility cannot be explained by the futures market.

After Turkish Derivatives Exchange (TurkDEX) was registered in Registry of Commerce in July 4, 2001, futures contract started in the beginning of February 2005. Since that time in Turkey, there have been very few studies which have examined the impact of the introduction of index futures on the volatility of the underlying spot market. The first study on this topic was rendered by By Baklac1 and Tütek (2006) who investigated if futures trading could improve the rate at which new information is impounded into the spot prices and have a persistence effect by using GARCH model. They indicated that the existence of future market significantly improves the rate at which new information is impounded into the spot prices and reduce the persistence of volatility in underlying spot market. Kasman and Kasman (2008) using the EGARCH model, examined whether or not stock index futures trading had a negative impact on the daily volatility of the underlying spot market in Turkey. The results showed there has been a decrease in the volatility following the introduction of the stock index futures. Their findings suggest that, derivatives could help to stabilize the spot markets of the countries that have similar characteristics of Turkish stock market. Their findings also entail that policymakers do not need to impose a larger regulation to the derivative markets since they could limit the possibility of investment and decrease the efficiency of the markets. Gökbulut et al. (2009) employed ARCH type models in order to analyze the effects of futures trading over the daily stock market volatility. As a result of their findings they argued that introduction of stock index futures have no significant impact over the associated spot market volatility. Özen, Bozdoğan and Züğül (2009) examined to determine whether a short term and long term relationship of causality between the IMKB 30 index and the futures transactions carried out in Izmir Derivatives Exchange (VOB) over Istanbul Stock Exchange Index 30 (İMKB30) exists or not. The analysis was applied from 4 February 2005 to 27 February 2009 by using Unit Root test, Co integration test and causality analysis depending on Error correction model. The findings reveals that the series derived from the futures prices and cash market prices were as stationary as each other and co integrated. Moreover when the causality between futures prices and cash prices was investigated, causality from VOB towards IMKB was detected in long term and in short term, IMKB was found to be the causal of VOB. Kapusuzoğlu and Taşdemir (2010), investigated the ISE National 100 market efficiency on the forward transaction and option exchange and its effect on the spot transaction prices by considering in-depth the contracts being carried out on the basis of Istanbul Stock Exchange (ISE) National 100 index in the Futures Transaction and Option Exchange in Turkey from 01.11.2005 to 30.06.2009 by using the unit root test, the co-integration test and the test of causality. The authors researched the impact of the Derivative Exchange transactions on the efficiency of the ISE National 100 market as well as on the spot market transaction prices in Turkey. The results indicate that the futures market price is not effective on the spot market price. On the contrary of expected, the spot market price is effective on the futures market price. Çağlayan (2011) investigated the impact of index futures on the volatility of the underlying Turkish spot market by using the Istanbul Stock Exchange 30 Index (BIST30) daily returns. In this study, the symmetric and asymmetric conditional volatility models were employed and the results indicated that introduction of futures trading 
significantly resulted a decrease in the volatility as well as in the volatility persistence.

In this article, we used intraday returns data in order to investigate the effect of introduction of futures on the volatility of the associated spot market. Our high frequency (intra-day data) sample set differs the study from the previous research in the literature. Moreover, the long sample period we used and 5 minutes returns data to compared to the previous research in the related literature. Besides, we used BIST National 100 Index as a proxy variable in our study. This article represents one of the very few studies investigating the Turkish futures market. At this point, it is necessary to highlight that the Turkish market is one of the leading emerging markets around the global world. Recent developments in global economy strengthen the position of Turkish market among global financial markets. Thus for a better understanding of the emerging markets around the world Turkish market may be a good benchmark point.

The rest of this article is planned as follows. In the following section, we briefly describe the current situation in the Turkish market focusing on the Borsa İstanbul (BIST) and Borsa İstanbul 30 Futures (BIST 30 Futures). Section 3 describes the data and discusses the methodology used in the analysis. Finally, Section 4 discusses the empirical findings and concludes.

\section{Borsa İstanbul (BIST) and Borsa İstanbul 30 Futures (BIST30 Futures)}

In recent years Turkish economy is one of the fastest growing economies even in E.U. region or in the OECD. Despite the deep recession in global markets, Turkish market exhibited a rapid recovery process pursuant to efficient regulation and supervision by the authorities. Moreover, during this period world leading rating agencies stated that Turkish economy is resilient to external shocks. These developments in Turkish economy made the global investors to pay more attention to the Turkish capital markets, especially Istanbul Stock Exchange. Accordingly, capital inflows to Turkish capital markets increased significantly in this period.

Istanbul Stock Exchange was settled on December 26, 1985 for ensuring that securities are traded in a secure and stable environment and started to operate on January 3, 1986. The BIST has contributed to the development of Turkish Capital Markets and Turkish Economy since the date of its establishment. Stocks and rights coupons of companies from various sectors are traded on BIST Stock Market. Trades are completed automatically on the Stock Market according to "Multiple Price - Continuous Auction" principle based on price and time priority rule by the electronic trading system. Trades are completed in two trading sessions as the morning and afternoon sessions, morning from 09:30 to 12:30 and afternoon from 14:00 to 17:00. An "Opening Session" based on the Single Price System is organized at the beginning of the first session in the morning. BIST Stock Market Indices are designed to measure the price and return performances of the stocks traded on the Exchange on an aggregate and sectoral. BIST Price Indices are calculated and announced throughout the whole sessions and return indices only at the end of the session. BIST National 30 Index is a capitalization-weighted index and consists of 30 stocks which are selected among the companies, except investment trusts, traded on National Market under the criteria set by BIST. BIST National 30 Index includes the stocks of 30 companies with the highest average daily trading volume.

Turkish Derivatives Exchange (TurkDEX) started its operation, formal trading in futures contract started in the beginning of February 2005. The TurkDEX is the only entity authorized by the Capital Markets Board (CMB) to launch a derivatives exchange in Turkey and according to the CMB regulations, membership to the TurkDEX is restricted to financial intermediaries. Clearing is handled by the BIST Settlement and the Custody Bank Inc. (Takasbank). The TurkDEX has a fully electronic exchange system with remote access. A single trading session called "normal session" shall be held between 9.15 a.m. and 5.15 p.m. In a normal session transactions are completed based on the price and time priority rule and continuous auctioning. In TurkDEX, only futures contracts are traded. Options trading have not been listed yet. Trading in the futures market has grown rapidly in recent years. In year 2013, the merger of Turkish Derivatives Exchange (TurkDEX) and Borsa İstanbul Futures \& Options Market (VIOP) trading platforms has been completed. Thenceforth, all future and option contracts in Turkey are traded in Borsa İstanbul Futures \& Options Market. All contracts in TurkDEX migrated to VİOP including TurkDEX30 but it is de-listed as BIST30 Futures thereafter.

\section{Data and Methodology}

This paper represents one of the very few studies looking into the Turkish spot market and in particular the Turkish futures market. In order to detect the real changes in volatility we have decided to use 5 minutes returns. Because as time span increases the real changes in volatility disappears. Besides 5 minutes data is the highest frequency used in the previous studies in literature (Ryoo and Smith 2004). Beyond that this data is unique as it uses 5-minute Turkish data with a long time span. A serious and though effort is required to achieve the data set used in the analysis form the raw data. At this point it should be highlighted that the data set we used is exceptional and not publicly available.

The data set have been prepared by using BIST National 30 and BIST National 100 Index prices. Data on BIST National 30 and BIST National 100 Index for the spot market were provided from Istanbul Stock 
Exchange. The sample covers September 1, 2000 and June 30, 2010, which corresponds to 2340 trading days and 118.860 data. The start of the sample is dictated by the introduction of BIST National 30 index futures trading and by the introduction of the 2008 financial crisis while the end of the samples represent the for which data were available at the time the empirical analysis began. Matched data using BIST National 30 and BIST National 100 prices was generated by Ms Excel software. Each BIST National 30 price was matched with the BIST National 100 price at the same 5 minute. For example, the data for the BIST National 30 price between 10.00 a.m to 10.30 a.m. are matched with the data for the BIST National 100 price between 10.00 a.m to 10.30 a.m. BIST National 100 index was used as a proxy variable. From these 5-minute data we generated the return series for each market. The results were obtained based on $R_{t}$, which is the rate of return $\mathrm{R}$ in period $\mathrm{t}$, calculated in the logarithmic first difference, $R_{t}=\ln \left(p_{t} / p_{t-1}\right) * 100$ where $p_{t}$ is the value of stock price index at the end of period $t$.

In order to use the correct model, the underlying assumptions have to be tested and verified. Table $\mathbf{1}$ provides descriptive statistics for 5 minutes BIST National 30 spot returns for the entire, pre-futures and postfutures, pre-crisis and post-crisis periods. For all the periods, the average daily return is positive. Following the introduction of index futures and 2008 financial crisis the standard deviation of returns for two periods decreased significantly. Jarque-Bera test of normality showed there are significant departures from normality at one percent level and besides, entire, pre-futures and pre-crisis period series are positively skewed and leptokurtic in contrast the post-futures and post-crisis series are negatively skewed and leptokurtic.

Table 1. Descriptive Statistics

\begin{tabular}{|c|c|c|c|c|c|}
\hline \multicolumn{6}{|c|}{ BIST 30} \\
\hline & $\begin{array}{l}\text { Entire } \\
\text { Period }\end{array}$ & Pre-Futures & Post-Futures & Pre-Crisis & Post-Crisis \\
\hline Mean & 0.0000122 & 0.0000173 & 0.00000902 & 0.0000184 & 0.00000161 \\
\hline Median & 0.00000751 & 0.00000528 & 0.00000879 & 0.00000620 & 0.0000109 \\
\hline Maximum & 0.156638 & 0.156638 & 0.078308 & 0.156638 & 0.078308 \\
\hline Minimum & -0.084886 & -0.070982 & -0.084886 & -0.083703 & -0.084886 \\
\hline Std. Dev. & 0.003693 & 0.004693 & 0.002927 & 0.004014 & 0.003085 \\
\hline Skewness & 1.491983 & 1.052578 & -1.040796 & 0.855837 & -0.894916 \\
\hline Kurtosis & 80.09554 & 60.84435 & 82.50683 & 73.35405 & 88.20809 \\
\hline Jarque-Bera & 29440830 & 6247241 & 19532346 & 15303808 & 13527571 \\
\hline JB-Probability & 0.000000 & 0.000000 & 0.000000 & 0.000000 & 0.000000 \\
\hline ADF Unit Root & $-208.0016^{*}$ & $-218.5772^{*}$ & $-166.3384^{*}$ & $-163.6850^{*}$ & $-128.8275^{*}$ \\
\hline P-P Unit Root & $-354.2709^{*}$ & $-218.5315^{*}$ & $-277.6208^{*}$ & $-280.9395^{*}$ & $-215.5460^{*}$ \\
\hline$Q(10)$ & $\begin{array}{l}229.91 \\
0.000^{*}\end{array}$ & $\begin{array}{l}99.675 \\
0.000^{*}\end{array}$ & $\begin{array}{l}176.64 \\
0.000^{*}\end{array}$ & $\begin{array}{l}161.92 \\
0.000^{*}\end{array}$ & $\begin{array}{l}107.72 \\
0.000^{*}\end{array}$ \\
\hline$Q^{2}(10)$ & $\begin{array}{l}1557.3 \\
0.000^{*}\end{array}$ & $\begin{array}{l}772.72 \\
0.000^{*}\end{array}$ & $\begin{array}{l}118.56 \\
0.000^{*}\end{array}$ & $\begin{array}{l}1296.1 \\
0.000^{*}\end{array}$ & $\begin{array}{l}80.433 \\
0.000^{*}\end{array}$ \\
\hline ARCH LM (1) & $\begin{array}{c}572.9595 \\
0.000^{*}\end{array}$ & $\begin{array}{c}372.7046 \\
0.000^{*}\end{array}$ & $\begin{array}{c}33.57424 \\
0.000^{*}\end{array}$ & $\begin{array}{c}492.3412 \\
0.000^{*}\end{array}$ & $\begin{array}{c}15.58768 \\
0.000^{*}\end{array}$ \\
\hline Observations & 118860 & 44752 & 74108 & 74162 & 44698 \\
\hline
\end{tabular}

Note: This table reports the mean, standard deviation, skewness and kurtosis of the five minutes percentage returns of the BIST National 30 index, Jarque-Bera test statistic for normality. The whole period is from $09 / 01 / 2000$ to $06 / 30 / 2010$, pre-futures from 09/01/2000 to 02/03/2005, post-futures from 02/04/2005 to 06/30/2010, pre-crisis from 09/01/2000 to 08/06/2007 and post-crisis from 08/07/2007 to 06/30/2010. The sample size differs as the transactions between the four periods differ.

indicate significance at the $1 \%,{ }^{* *}$ indicate significance at the $5 \%$

Augmented Dickey-Fuller and Phillips-Perron unit root tests are employed for the natural logarithms of the BIST National 30 spot and National 100 spot indices. We find both series are integrated of level 0 . The order of integration is the number of unit roots contained in the series or the number of differencing operations it takes to make the series stationary.

To test the presence of autocorrelation, the Ljung-Box Q-statistics for the standardised residuals and squared standardised residuals conducted up to 10 lags. The results show that each of return series have autocorrelation in all periods therefore, we can reject the null hypothesis that there is no serial correlation. Furthermore the $\mathrm{Q}^{2}$ statistics indicate the presence of statically significant ARCH effects. The ARCH LM test statistics are very significant suggesting the presence of $\mathrm{ARCH}$ in all the in the conditional variance at lag one.

All this evidence suggests that the return series fallow the ARCH-type dependencies, and therefore, it can be concluded that EGARCH model are appropriate for volatility estimations.

In this study, conditional mean equation was constructed to capture serial dependence in the data. In the 
specification of the conditional mean equation, Box-Jenkins approach and estimated ARMA (p, q) models. AR (p) and MA (q) orders were determined according to the Akaike Information Criterion (AIC) and Schwarz Criterion (SC). The conditional mean of BIST National 30 entire series was modeled as ARMA(2,2); prefutures and pre-crisis were modeled as $\operatorname{ARMA}(1,1)$; post-crisis and post-futures were modeled as $\operatorname{ARMA}(0,3)$.

BIST 30 index return series seems best described by an unconditional leptokurtic distribution and possesses significant conditional heteroscedasticity. The EGARCH model with generalized error distribution (GED) should generate better results than a normal distribution.

For a better estimation of non-constant volatility in financial markets, Engle (1982) developed Auto Regressive Conditional Heteroskedasticity which is then extended as Generalized Auto Regressive Conditional Heteroskedasticity model by Bollerslev (1986). Nelson (1991) presented a new class of ARCH models that allows measuring the asymmetric effect of new information, Exponential GARCH (EGARCH) models. Besides in this type of ARCH models conditional variance equation is in log-linear form and EGARCH model does not require non-negativity constraints for the coefficients.

In this article we examined the effect of futures trading on spot market return volatility with GARCH $(1,1)$ models, such as Holmes (1996), Ryoo and Smith (2004), Kasman and Kasman (2008), Harris (1989), Bologna and Cavallos (2002), Drimbetas et. al (2007). The model that has been described here is an extension of typical GARCH $(1,1)$ model of Holmes (1996).

In order to find out the impact of futures Holmes (1996) used a proxy variable1 to isolate price volatility specific to spot market related to the introduction of futures. The proxy variable should be chosen carefully. In this paper BIST National 100 index is chosen as it is generally used as a proxy for the whole stock exchange market in Turkey in finance literature. A dummy variable is included in the variance equation, takes the values zero for the pre-futures period and pre-crisis period; one for the post-futures period and post-crisis period.

The EGARCH( $(1,1)$ model with dummy variable is specified as follows:

$$
\boldsymbol{h}_{t}=\alpha_{0}+\alpha_{1}\left(\frac{u_{t-1}^{\mathbf{2}}}{\boldsymbol{h}_{t-1}}\right)+\lambda_{1}\left|\frac{u_{t-1}^{\mathbf{2}}}{\boldsymbol{h}_{t-1}}\right|+\beta_{1} \boldsymbol{h}_{t-1}+\gamma_{1} \text { Dummy } y_{t} \text { Eq. (1. b) }
$$

In order to check the model, if it is designed adequately, someone should perform diagnostic tests. Diagnostic testing of the squared residuals indicates that the EGARCH $(1,1)$ model provides a satisfactory explanation. For an adequate model, there must be no ARCH effect left in the standardized residuals. In the model the statistics for the squared residuals are not statistically significant; also the ARCH LM and F statistics shows no serial dependence left in squared residuals.

Simply, the diagnostic tests results for the EGARCH $(1,1)$ model, suggest that the model is reasonably well designed in order to capture the ARCH effects. Hereby we can now proceed to discuss the estimation results of the model.

As mentioned before, different combinations of GARCH and EGARCH $(\mathrm{p}, \mathrm{q})$ equations are estimated but according to diagnostic tests results EGARCH $(1,1)$ and entire series was modeled as ARMA(2,2); pre-futures and pre-crisis were modeled as $\operatorname{ARMA}(1,1)$; post-crisis and post-futures were modeled as $\operatorname{ARMA}(0,3)$. Accordingly, EGARCH $(1,1)$ and ARMA models are selected and the estimation results for this model are represented below. The results for separate EGARCH $(1,1)$ models for the five periods; entire period, pre and post-futures periods, pre and post-crisis periods are reported in the first to third rows of Table 2.

Table 2. EGARCH $(\mathbf{1 , 1})$ Model (Dummy variable included) ${ }^{2}$

\begin{tabular}{|l|l|l|l|l|l|}
\hline Estimation Period & \multicolumn{5}{|l|}{} \\
\hline & $\widehat{\alpha}_{\mathbf{0}}$ & $\widehat{\alpha}_{\mathbf{1}}$ & $\widehat{\lambda}_{\mathbf{2}}$ & $\widehat{\beta}_{\mathbf{1}}$ & $\widehat{\gamma}_{\mathbf{1}}$ \\
\hline Entire Period & -1.3851 & 0.7624 & 0.0135 & 0.7425 & -0.2069 \\
& $(0.000)^{*}$ & $(0.000)^{*}$ & $(0.002)$ & $(0.000)^{*}$ & \\
\hline Pre-Futures Period & -1.3323 & 0.8331 & 0.0201 & 0.6743 & -0.3054 \\
& $(0.000)^{*}$ & $(0.000)^{*}$ & $(0.021)^{*}$ & $(0.000)^{*}$ & \\
\hline Post-Futures Period & -1.4692 & 0.7309 & 0.0087 & 0.7478 & -0.2782 \\
& $(0.000)^{*}$ & $(0.000)^{*}$ & $(0.0777)$ & $(0.000)^{*}$ & \\
\hline Pre-Crisis Period & -1.3492 & 0.8403 & 0.0190 & 0.6676 & -0.3120 \\
& $(0.000)^{*}$ & $(0.000)^{*}$ & $(0.000)^{*}$ & $(0.000)^{*}$ & \\
\hline Post-Crisis Period & -1.3790 & 0.7197 & 0.0070 & 0.7810 & -0.0520 \\
& $(0.000)^{*}$ & $(0.000)^{*}$ & $(0.000)^{*}$ & $(0.000)^{*}$ & \\
\hline & Notes: Figures in parenthesis are p values, & & \\
\hline
\end{tabular}

In GARCH type models, large values of $\alpha$ and $\beta$ indicates high level of conditional volatility. The larger is

\footnotetext{
${ }^{1}$ Proxy variable were used to some papers such as Holmes P. (1996), Ryoo H. and Smith G. (2004), Pok and Poshakwale (2004).

${ }^{2}$ Dummy variables were used to some papers such as Ryoo and Smith (2004), Pok and Poshakwale (2004), Kasman and Kasman(2008).
} 
$\alpha_{\mathbf{1}}$, the larger is the response of the conditional variance to shocks (new information). The ARCH parameter

$\alpha_{1}$ represents the level of volatility. On the other side, $\beta_{\mathbf{1}}$ measures the persistence in conditional volatility irrespective of anything happening in the market. A high $\beta_{1}$ shows persistence of volatility according to old news. When $\beta_{1}$ is relatively large, then volatility takes a long time to die out following a shock in the market. The $\hat{\lambda}_{1}$ parameter measures the asymmetry or the leverage effect, the parameter of importance so that the EGARCH model allows for testing of asymmetries. If $\lambda=0$, then the model is symmetric. When $\lambda<0$, then a positive shock (good news) generate less volatility than negative shocks (bad news). When $\lambda>0$, it implies that positive shocks will have larger effects than the negative shocks.

According to the estimation results in for futures periods Table 2, the estimated coefficient $\hat{\boldsymbol{\alpha}}_{\mathbf{1}}$ is 0.8331 in the pre-futures period and 0.7309 in the post-futures period. There is nearly $12 \%$ drop in volatility. The impact of news is also captured by the coefficient $\widehat{\boldsymbol{\alpha}}_{\mathbf{1}}$ in GARCH equations. Thus the larger $\hat{\boldsymbol{\alpha}}_{\mathbf{1}}$ coefficient in the prefutures period suggests news is reflected in share prices more quickly in the pre-futures then in the post-futures period. The reaction speed of the market to the new information, decreased after the introduction of the futures. It could be accepted as the evidence for the lower level of market efficiency after the introduction of futures. The post-futures period also covers the 2007 global financial crisis. Therefore the adverse effects of 2008 global financial crisis may be the reason for this fall.

A decrease in $\hat{\boldsymbol{\alpha}}_{\mathbf{1}}$ is expected to increase $\widehat{\boldsymbol{\beta}}_{\mathbf{1}}$ because the fall in the rate of flow of recent news would cause old news to have more impact on today's price changes. This is confirmed by an increase in estimated coefficient of $\widehat{\boldsymbol{\beta}}_{\mathbf{1}}$ from 0.6743 to 0.7478 in the post-futures period. $\widehat{\boldsymbol{\beta}}_{\mathbf{1}}$ is 0.7478 in the pre-futures period and increased $10 \%$ to 0.6743 in the post-futures period. As noted before larger $\widehat{\boldsymbol{\beta}}_{\mathbf{1}}$ indicates higher persistence in volatility. This is consistent with the theory. The lower the market reaction to the news is the more persistent is the volatility. This surprising result merits further investigation. The persistence of volatility shocks depends primarily on the value of $\widehat{\boldsymbol{\beta}}_{\mathbf{1}}$ coefficient. However the increase in volatility needs further investigation as the sample period covers the global financial crisis of 2008 .

The estimated coefficient $\hat{\lambda}_{\mathbf{1}}$ is negative but statistically significant for pre-futures period. That means there is leverage (asymmetric) effect in the returns during the sample period. Positive shocks (good news) generate less volatility than negative shocks (bad news). This is a remarkable result as the leverage effect is expected to be negative in financial markets. But $\hat{\lambda}_{\mathbf{1}}$ is negative but statistically insignificant for post-futures period. The result shows that there is no asymmetric effect that is positive and negative shocks of the same magnitude have similar impact and effect on the volatility level.

Moreover the estimated coefficient $\widehat{\gamma_{1}}$ (dummy variable) are negative for three futures periods and significant implying that the introduction of stock index futures induced a decrease in volatility in the associated spot market. These results are consistent with some of the previous studies in literature (Pradhan 2008, Tripathy et al. 2009, Srinivasan and Bhat 2008, Drimbetas et al. 2007, Antoniou, Holmes and Priestly 1998).

According to the estimation results for crisis periods in Table 2, the estimated coefficient $\hat{\boldsymbol{\alpha}}_{\mathbf{1}}$ is 0.8403 in the pre-futures period and 0.7197 in the post-futures period. There is nearly $14.3 \%$ drop in volatility. The impact of news is also captured by the coefficient $\hat{\boldsymbol{\alpha}}_{\mathbf{1}}$ in GARCH equations. Thus the larger $\hat{\boldsymbol{\alpha}}_{\mathbf{1}}$ coefficient in the prefutures period suggests news is reflected in share prices more quickly in the pre-futures then in the post-futures period. The reaction speed of the market to the new information, decreased after the introduction of the futures. It could be accepted as the evidence for the lower level of market efficiency after the introduction of futures. The post-futures period also covers the 2007 global financial crisis. Therefore the adverse effects of 2008 global financial crisis may be the reason for this fall.

A decrease in $\widehat{\boldsymbol{\alpha}}_{\mathbf{1}}$ is expected to increase $\widehat{\boldsymbol{\beta}}_{\mathbf{1}}$ because the fall in the rate of flow of recent news would cause old news to have more impact on today's price changes. This is confirmed by an increase in estimated coefficient of $\widehat{\boldsymbol{\beta}}_{\mathbf{1}}$ from 0.6676 to 0.7810 in the post-futures period. $\widehat{\boldsymbol{\beta}}_{\mathbf{1}}$ is increased $14.5 \%$ in the post-futures period. As noted before larger $\widehat{\boldsymbol{\beta}}_{\mathbf{1}}$ indicates higher persistence in volatility. This is consistent with the theory. The lower the market reaction to the news is the more persistent is the volatility. The persistence of volatility shocks depends primarily on the value of $\widehat{\boldsymbol{\beta}}_{\mathbf{1}}$ coefficient.

The estimated coefficient $\hat{\lambda}_{1}$ is positive for all the periods. These results indicate that positive shocks are more destabilizing then the negative shocks for all the periods. This is a remarkable result as the leverage effect is expected to be negative in financial markets. However investors may overreact to both bad news and good news. After a long period of stock market growth, they tend to become more optimistic. Thus they overreact to 
the good news while they under react to the bad news.

Moreover the estimated coefficient $\widehat{\gamma_{1}}$ are negative for three futures periods and significant implying that the introduction of stock index futures induced a decrease in volatility in the associated spot market.

\section{Conclusion}

In this study EGARCH model was employed in order to investigate the impact of index futures on spot market volatility of the Turkish Stock Exchange by using the BIST30 index. The data set were divided into four subperiods which were called pre-futures period, post-futures period, pre-crisis period, post crises period and also entire period in order to . EGARCH $(1,1)$ model was selected by implying GED distribution.

In this paper we have investigated the impact of the futures market on spot market volatility in Turkey and achieved some important results. First, the results show that the introduction of futures decreases the speed at which information is reflected in spot market prices. In general this is accepted as an indicator of an inefficient market. In emerging markets investors tend to be overly sensitive to new information. These investors' quick decisions have immediate impact on market prices. On the contrary, investors in developed markets are more calculated in decision making. The difference in investors' behavior due to the psychological impact of their respective market environments may influence the speed with which new information is reflected in those markets. Therefore, the decrease in reflection speed could instead be considered a sign of a developed market. Because structural properties of the market may be the reason for this situation, it might be necessary for researchers to look more extensively at this subject in the future.

Second, there has been a decrease in volatility but an increase in volatility persistence following the introduction of stock index futures. The decrease in the volatility of the spot market is in line with previous studies (Bessembindner and Sequin 1992, Antoniou et al. 1998, Drimbetas et al. 2007, Kasman and Kasman, 2008). The lower level of volatility could be considered a sign of market development. Although the increase in volatility persistence might be due to the destabilizing effects of futures trading associated with speculation, stock index futures added a new dimension to the market by providing a new control to facilitate hedging. This issue should be taken into account by the regulation authority.

Third, the results revealed that good news generate less volatility than bad news in the pre-futures period whereas different types of news have the same impact of the volatility level in the post-futures period. These results indicated that the speed and nature of information differ between pre-futures period and post-futures period.

Fourth, since the introduction of index futures trading in Turkish Stock Market, there have been very few studies. To our knowledge, this research paper is one of the very few studies investigating the effect of the introduction of index futures on the volatility of the spot market using five minutes data.

Finally, in light of our empirical findings, it is possible to say that the introduction of futures appear to have been beneficial for the Turkish stock market. The results from this study can be used as a point of comparison to research into similar emerging markets.

\section{Acknowledgements}

The data used in this research is taken from Borsa İstanbul.

\section{Disclosure statement}

No potential conflict of interest was reported by the authors.

\section{REFERENCES}

Alexakis, P. (2007):“On The Effect of Index Futures Trading on Stock Market Volatility”. International Research Journal of Finance and Economics, 11: 7-20.

Antoniou A, Holmes P (1995): Futures Trading, Information and Spot Price Volatility: Evidence For The FTSE100 Stock Index Futures Contract Using GARCH. Journal of Banking \& Finance, 19: 117-129.

Antoniou A, Holmes P, Priestly R (1998): The Effects of Stock Index Futures Trading on Stock Index Volatility: An Analysis of The Asymmetric Response of Volatility to News. The Journal of Futures Markets, 18 (2): 151-166.

Baklac1, H, Tütek, H. (2006): The Impact of the Futures Market on Spot Volatility: An Analysis in Turkish Derivatives Markets, Computational Finance and Its Applications II, WIT Transactions on Modelling and Simulation, (43): 237-246.

Bessembindner H, Seguin P.J (Dec. 1992): Futures-Trading Activity And Stock Price Volatility, The Journal Of Finance, XLVII (5): 2015-2034.

Bollerslev T (1986): Generalized Autoregressive Conditional Heteroskedasticity. Journal of Econometrics, 31: 307-327.

Bologna P, Cavallo L (2002): Does the Introduction of Stock Index Futures Effectively Reduce Stock Market 
Volatility? Is the 'Futures Effect' Immediate? Evidence From The Italian Stock Exvhange Using GARCH. Applied Financial Economics, (12): 183-192.

Brooks C, Rew A.G, Ritson S (2001). A Trading Strategy Based on The Lead-Lag Relationship Between The Spot Index And Futures Contract for The FTSE 100. International Journal of Forecasting (17): $31-44$.

Çağlayan, E (2011): The Impact of Stock Index Futures on the Turkish Spot Market. Journal of Emerging Market Finance 10 (1): 73-91.

Chiang M, Wang C (2002): The Impact Of Futures Trading On Spot Index Volatility: Evidence For Taiwan Index Futures. Applied Economics Letters, 9: 381-385.

Choi H, Subrahmanyan A (1994): Using Intraday Data To Test For Effects Of Index Futures On The Underlying Stock Markets. The Journal Of Futures Markets, 14 (3): 293-322.

Darrat A.F, Rahman S (1995): Has Futures Trading Activity Caused Stock Price Volatility. The Journal Of Futures Markets, 15 (5): 537-557.

Drimbetas E, Sariannidis N, Porfiris N (2007): The Effect of Derivatives Trading on Volatility of The Underlying Asset: Evidence From The Greek Stock Market. Applied Financial Economics, (17): 139-148.

Engle R.F. (1982): Autoregressive Conditional Heteroscedasticity with Estimates of the Variance of United Kingdom Inflation. Econometrica, 50 (4): 1987-1007.

Floros, C. and D. V. Vougas (2006): Index Futures Trading, Information and Stock Market Volatility: The Case of Greece. Derivatives Use, Trading \& Regulation 12(1-2): 146-166.

Fong L., Han C. (2015): Impacts of Derivative Markets on Spot Market Volatility and Their Persistence. Applied Economics, Durham University Durham Research Online, 1-16.

Gökbulut İ. R., Köseoğlu S. D., Atakan T (2009). "The Effects of the Stock Index Futures to the Spot Stock Market: A Study for the Istanbul Stock Exchange." Journal of the School of Business Administration, Istanbul University 38 (1): 84-100.

Gulen H, Mayhew S (2000): Stock Index Futures Trading And Volatility In International Equity Markets. The Journal Of Futures Markets, 20 (7): 661-685.

Haris L (December 1989): S\&P 500 Cash Stock Price Volatilities. Journal of Finance, 44 (5): 1155-1175.

Holmes P, (1996): Spot Price Volatility, Information and Futures Trading: Evidence From a Thinly Traded Market. Applied Economic Letters, 3: 63-66.

Illueca M, Lafuente J. A (2003): The Effect Of Spot And Futures Trading On Stock Index Market Voaltility: A Nonparametric Approach. The Journal Of Futures Markets, 23 (9): 841-858.

Kapusuzoğlu A, Taşdemir A, (2010), The Analysis of the Effects of Derivatives Exchange (DE) Transactions on the Market Efficiency of Istanbul Stock Exchange (ISE) National 100 Index and on Spot Market Transaction Prices, African Journal of Business Management, 4 (2): 242-247.

Kasman A, Kasman S (2008): The Impact of Futures Trading on Volatility of The Underlying Asset In The Turkish Stock Market. Physica A 387, Faculty of Business Department of Economics, Dokuz Eylul University, 2837-2845.

Nelson D.B. (1991) Conditional Heteroskedasticity in Asset Returns: A New Approach. Econometrica, 59 (2): 347-370.

Özen E., Bozdoğan T. and Züğül M., (2009): The Relationship of the Causality Between Price of Futures Transactions Underlying Stock Exchange and Price of Cash Market: The Case of Turkey, Middle Eastern Finance and Economics, 4: 28-37.

Pati P. C., Rajib P (2011): Intraday Return Dynamics and Volatility Spillovers between NSE S\&P CNX Nifty Stock Index and Stock Index Futures. Applied Economics Letters, 18(6): 567-574.

Pilar C, Rafael S (2002): Does Derivatives Trading Destabilize the Underlying Assets ? Evidence From The Spanish Stock Market. Applied Economics Letters, (9): 107-110

Pradhan K. C., Bhat K. S (2008): An Empirical Analysis of the Impact of Futures on Spot Market Volatility: Evidence from National Stock Exchange (NSE), India. Indian Journal of Economics \& Business, 7 (2): 247-253.

Pok W. C, Poshakwale S (2004): The Impact of The Introduction of Futures Contracts on The Spot Market Volatility: The Case of Kuala Lumpur Stock Exchange. Applied Financial Economics, (14): 143-154.

Ryoo H. Smith G (2004): The Impact of Stock Index Futures on The Korean Stock Market. Applied Financial Economics, (14): 243-251.

Sequeira J.M, Chiat P.C, McAleer M (2004): Volatility Models Of Currency Futures In Developed And Emerging Markets. Mathematics and Computers in Simulation, (64): 79-93.

Spyros I. Spyrou, (2005): Index Futures Trading and Spot Price Volatility: Evidence from an Emerging Market, Journal of Emerging Market, Finance, August, Vol.4, No.2, 151-167.

P. Srinivasan and K. Sham Bhat, (2008): The Impact of Futures Trading on the Spot Market Volatility of Selected Commercial Banks in India, 29-41.

Tripathy N, Rao S.V.R., Kanagaraj A (2009): Impact of Derivatives Trading on Spot Market Volatility: An 
Empirical Study. International Journal of Applied Decision Sciences, 2 (2): 209 - 232.

Yilgor A, Mebounou C.L.C (2016): The Effect of Futures Contracts on the Stock Market Volatility: An Application on Istanbul Stock Exchange. Journal of Business, Economics and Finance, 5 (3): 2146 - 7943.

Xie S., Huang J (2014): The Impact of Index Futures on Spot Market Volatility in China. Emerging Markets Finance \& Trade, January-February 2014, 50 (1): 167-177. 